University of Rhode Island

DigitalCommons@URI

The Rhode Island Current Conditions Index

Economics

2-2006

\title{
Rhode Island Current Conditions Index - February 2006
}

Leonard Lardaro

University of Rhode Island, lardaro@uri.edu

Follow this and additional works at: https://digitalcommons.uri.edu/ricci

Part of the Econometrics Commons

Terms of Use

All rights reserved under copyright.

\section{Recommended Citation}

Lardaro, Leonard, "Rhode Island Current Conditions Index -- February 2006" (2006). The Rhode Island Current Conditions Index. Paper 81.

https://digitalcommons.uri.edu/ricci/81

This Article is brought to you for free and open access by the Economics at DigitalCommons@URI. It has been accepted for inclusion in The Rhode Island Current Conditions Index by an authorized administrator of DigitalCommons@URI.For more information, please contact digitalcommons-group@uri.edu. 


\section{GURRENT}

Effective this month, one of the original twelve Current Conditions Index indicators, Help Wanted Advertising for Providence, RI, will be replaced by Employment Services Jobs in Rhode Island. Help Wanted Advertising, which was once an important indicator, has lost a great deal of its predictive value over the years (it was actually a leading indicator). Its replacement is a more accurate leading indicator of how well Rhode Island's economy is performing.

Rhode Island's first quarter performance remained noticeably better than it was for much of 2005. The Current Conditions Index for February was 67, one notch below January's value of 75 , but still indicative of a solid overall performance. Eight of the twelve indicators improved, and several turned in solid performances. With the exception of US Consumer Sentiment and Retail Sales, the indicators that failed to improve showed less weakness than they had in recent months.

In February, Single-Unit Permits, which measure new home construction, rose by 2.6 percent above its value last February. At an annual rate, there were fewer than 2,000 permits. Retail Sales fell in February, by 1.8 percent. This decline was actually good in light of the fact that US

\begin{tabular}{lc}
\multicolumn{2}{c}{ CCI I ndicators - \% Change } \\
Government Employment & 0.2 Y \\
US Consumer Sentiment & -8.0 \\
Single-Unit Permits & $2.6 \mathbf{Y}$ \\
Retail Sales & -1.8 \\
Employment Services J obs & $2.8 \mathrm{Y}$ \\
Priv. Serv-Prod Employment & $1.4 \mathrm{Y}$ \\
Total Manufacturing Hours & -1.5 \\
Manufacturing Wage & $2.4 \mathbf{Y}$ \\
Labor Force & $1.8 \mathrm{Y}$ \\
Benefit Exhaustions & $-0.9 \mathrm{Y}$ \\
New Claims & $-5.8 \mathbf{Y}$ \\
Unemployment Rate & 2.0 \\
\multicolumn{1}{|c}{$\mathbf{Y}=$ I mproved Value } &
\end{tabular}

Consumer Sentiment remained weak, falling by 8 percent versus last February, its worst performance since October.

Benefit Exhaustions, which reflects long-term unemployment, and New Claims, a measure of layoffs, continued to improve, although their momentum appears to be slipping. Benefit Exhaustions fell by only 0.9 percent, but this was still its eighth decline in the last nine months. New Claims for Unemployment Insurance declined by 5.8 percent, the tenth consecutive month for which this indicator has improved. The recent strong performances by these two indicators is not entirely unexpected, since labor demand, as measured by Employment Services Jobs, has continued to display solid growth rates. For February, Employment Services J obs grew by 2.8 percent.

Our Labor Force continued its rapid growth, rising by 1.8 percent in February. As has been the case for some time now, this relatively high growth rate is largely the result of a weak "comp" last February. The true test for Labor Force growth will begin in April, when the "comps" return to levels more typical of what we have witnessed in recent years. Our Unemployment Rate rose slightly from 5 percent last February to 5.1 percent this February. This is actually a positive result in light of our Labor Force growth.

Government Employment rose slightly in February (by $0.2 \%$ ), with slow growth reflecting the effects of budget tightening. Private Service-Producing Employment grew again at a sluggish 1.4 percent rate, which is more rapid than the prior two months. Weakness in our goods-producing sector moderated, as the rate of decline in Total Manufacturing Hours slowed to 1.5 percent, with hours worked increasing while employment fell. Along with this, the Manufacturing Wage grew by 2.4 percent, its most rapid rate of increase since December of 2001.

While the increased momentum our state experienced in late 2005 has thus far been sustained in the first quarter of 2006, the signs of moderating growth that appeared in February's data may well become more pronounced as rising gas prices, higher interest rates, and our state's budget crisis slow the pace of economic activity here.

\section{Ca Over the Past 13 Months}

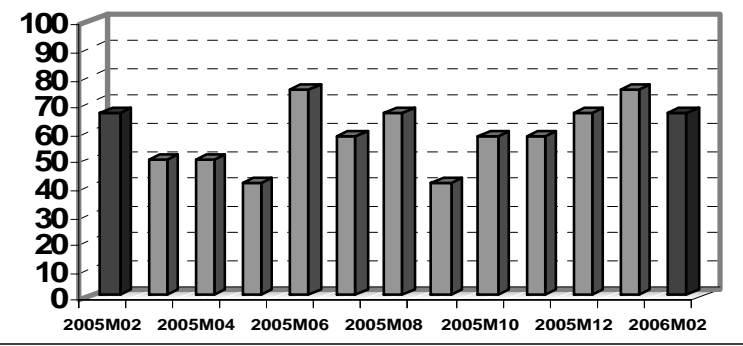

\begin{tabular}{|c|c|c|c|c|c|c|c|c|c|c|c|c|}
\hline & Jan & Feb & Mar & Apr & May & J un & J ul & Aug & Sep & Oct & Nov & Dec \\
\hline 2005 & 50 & 67 & $50 \downarrow$ & 50 & 42 & $75 \downarrow$ & 58 & 67 & $42 \downarrow$ & $58 \uparrow$ & 58 & $67 \uparrow$ \\
\hline 2006 & $75 \uparrow$ & 67 & & & & & & & & & & \\
\hline
\end{tabular}

